\title{
Plasma insulin in pancreatic disease
}

\author{
M. F. ANDERSON, S. H. H. DAVISON, A. P. DICK, C. N. HALES, AND \\ J. OWENS \\ From Addenbrooke's Hospital and the University Department of Biochemistry, Cambridge
}

SUMMARY Pancreatic exocrine function tests and plasma insulin curves after a glucose load
have been performed in 74 patients, 32 with no significant pancreatic disease, 31 with various
disorders of the pancreas, and 11 with postmature diabetes mellitus.

Exocrine function was impaired in all patients with chronic pancreatitis and chronic relapsing pancreatitis, whereas insulin production was defective in seven of 10 of those with chronic pancreatitis, and in one of seven with chronic relapsing pancreatitis. The findings in other examples of pancreatic disease are mentioned. Two out of four patients presenting with

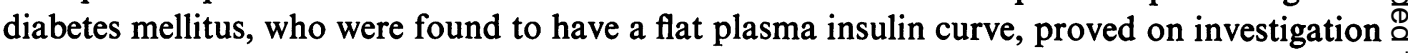
to have chronic pancreatitis.

The results of plasma insulin response curves in this series are discussed in relation to pancreatic disease and their possible value in diagnosis.

The value of tests of pancreatic exocrine function is well established (Burton, Evans, Harper, Howat, Oleesky, Scott, and Varley, 1960). Less is known about the changes which occur in plasma insulin levels in diseases of the pancreas. Peters, Dick, Hales, Orrell, and Sarner (1966), in a small series of cases, found that their patients with chronic pancreatitis showed an inadequate production of insulin, as compared with the normal, and were all mildly diabetic.

The patients with postmature diabetes mellitus, who showed greater abnormalities of glucose tolerance, had mean plasma insulin concentrations greater than the patients with chronic pancreatitis both after fasting and following oral glucose. It has been suggested that the mild diabetes of chronic pancreatitis differs from the ordinary type of diabetes in the infrequency of renal and vascular complications and the rarity of ketosis. A different mechanism of production of the diabetic state might be reflected in a different response of insulin production to a glucose load. Linquette, Fossati, Fourlinnie, and Received for publication 21 May 1969.
Paris (1968) examined the plasma insulin response to a glucose load in 28 patients with chronic

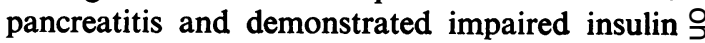
production in a proportion of their cases. Joffe, $D$ Bank, Jackson, Keller, O'Reilly, and Vinik (1968) approached the matter from a different aspect, testing the plasma insulin levels following a glucose load, the pancreas being stimulated 0 with intravenous tolbutamide and glucagon half $\mathbb{\omega}$ an hour after the glucose had been given. Using this method of islet cell stimulation they found low responses in all their patients with chronic $\mathbb{D}$ pancreatitis. Ohlsen (1968) has examined the insulin production in response to glucose infusion in 20 out of 27 patients with chronic pancreatitis, $\frac{O}{\mathbb{D}}$ who had not previously been treated with insulin.

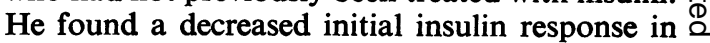
all of those with overt diabetes who could be tested.

Plasma insulin curves following a glucose load have now been performed in a series of 74 patients in whom pancreatic function was being studied. The 14 cases reported by Peters et al (1966) are included. The findings are reported in this paper. 


\section{Object of Study}

The object of this investigation has been first to obtain further information about the changes in plasma insulin production which may be found in various types of pancreatic disease, and in patients presenting with diabetes mellitus possibly due to pancreatic disease, and secondly to determine the practical value of the estimation of plasma insulin levels in the diagnosis and assessment of pancreatic disorders. It is clear that pancreatic disease may be associated with a reduction in insulin production. It was hoped that evidence might be found to indicate whether or not there was any correlation between impairment of exocrine and endocrine function. Arising from this, if plasma insulin production is at times impaired before the exocrine secretion is reduced, is the estimation of plasma insulin response to a glucose load of any value in the early diagnosis of pancreatic disease? Further, and from the aspect of endocrine dysfunction, does the finding of impaired insulin production in a patient presenting with diabetes mellitus, when there are no other symptoms to suggest the presence of pancreatic disease, call for investigation to try and exclude the presence of chronic pancreatitis or a carcinoma of the pancreas?

\section{Methods}

\section{EXOCRINE FUNCTION}

The method used has been previously described (Peters et al, 1966) and follows, with minor modifications, the technique of Burton et al (1960). Pancreatic juice was collected over two 10-minute control periods, three 10-minute periods after secretin injections, and three 10minute periods after pancreozymin injection. The volume of juice, the bicarbonate concentration, and the amylase content only were estimated in view of the finding of Burton et al (1960) that no advantage was gained from the simultaneous estimation of trypsin and lipase. The criteria of normality used in analysing our results for this test followed those described by Burton et al (1960).

\section{ENDOCRINE FUNCTION}

A standard two-hour oral glucose tolerance test was carried out, the dose of glucose being $50 \mathrm{~g}$. Blood glucose was estimated by the glucose oxidase method on the Technicon AutoAnalyzer (Wincey and Marks, 1961). This was considered to be abnormal, in accordance with the criteria described by Conn (1958), when the blood glucose exceeded one of the following levels: $160 \mathrm{mg}$ per $100 \mathrm{ml}$ at one hour, $140 \mathrm{mg}$ per $100 \mathrm{ml}$ at one and a half hours, or $120 \mathrm{mg}$ per $100 \mathrm{ml}$ at two hours.
Plasma insulin concentrations were measured on the same specimens of blood during the twohour oral glucose tolerance test, using the immunoassay described by Hales and Randle (1963). As regards the plasma insulin response to this oral glucose load, decreased insulin production was regarded as being shown first by a flat insulin curve, defined as a curve in which no value was more than twice the fasting plasma insulin, and second, a delayed rise, when the 30minute value was less than twice the fasting plasma insulin value, provided that the criteria for a flat curve were not present.

\section{Clinical Material}

Seventy-four cases have been investigated by combined exocrine and endocrine pancreatic function tests. The first group consisted of 32 patients in whom significant pancreatic disorder was excluded, in the light of investigation and subsequent course. All these patients, at some stage in their illness, had symptoms of abdominal pain and/or diarrhoea, or steatorrhoea, which led to a suspicion of pancreatic disease and the performance of pancreatic exocrine function tests. Insulin curves were done at the same time. The final diagnoses in these patients in group 1, who have served as controls, are shown in Table I.

The second group consisted of 31 cases of proved pancreatic disease, as shown in Table II. The patients who had had acute pancreatitis and those with relapsing acute pancreatitis all showed typical clinical features and a high serum amylase in the acute attack. Two of those with acute pancreatitis were operated on. Two out of the

\begin{tabular}{ll}
\hline Control Cases & Number \\
\hline Idiopathic steatorrhoea & 3 \\
Ulcerative colitis & 1 \\
Chronic post enteritic diarrhoea & 4 \\
Duodenal ulcer & 1 \\
Gastric ulcer & 1 \\
Hiatus hernia & 4 \\
Gallstones & 2 \\
Ischaemic gut disease & 1 \\
Hysteria & 2 \\
\hline
\end{tabular}

Table I Control cases

\begin{tabular}{lc}
\hline Pancreatic Disease & Number \\
\hline Postacute pancreatitis & 3 \\
Relapsing acute pancreatitis & 3 \\
Chronic relapsing pancreatitis & 7 \\
Chronic pancreatitis & 10 \\
Carcinoma of pancreas & 5 \\
Haemochromatosis & 2 \\
Fibrocystic disease & 1 \\
\hline
\end{tabular}

Table II Cases of pancreatic disease 


\begin{tabular}{|c|c|c|c|c|c|c|c|c|c|c|c|}
\hline Sex & Age & Attack & $\begin{array}{l}\text { Time } \\
\text { after } \\
\text { Attack } \\
\text { (months) }\end{array}$ & $\begin{array}{l}\text { Length of } \\
\text { History } \\
\text { (years) }\end{array}$ & Pain & $\begin{array}{l}\text { Gall- } \\
\text { stones }\end{array}$ & Alcoholism & $\begin{array}{l}\text { Pancreatic } \\
\text { Calcification }\end{array}$ & Obesity & $\begin{array}{l}\text { Raised } \\
\text { Serum } \\
\text { Amylase }\end{array}$ & $\begin{array}{l}\text { Clinical } \\
\text { Pancreatic } \\
\text { Insufficiency }\end{array}$ \\
\hline
\end{tabular}

\begin{tabular}{|c|c|c|c|c|c|c|c|c|c|c|c|c|}
\hline \multicolumn{13}{|c|}{ Acute pancreatitis } \\
\hline $\mathbf{M}$ & 59 & First & 3 & & + & - & - & - & + & + & - & + \\
\hline $\mathbf{F}$ & 60 & First & 1 & & + & + & - & - & - & + & - & - \\
\hline $\mathbf{M}$ & 56 & First & $i$ & & + & - & - & - & + & + & - & + \\
\hline \multicolumn{13}{|c|}{ Relapsing acute pancreatitis } \\
\hline $\mathbf{M}$ & 15 & Second & 1 & 1 & + & - & - & - & + & + & - & - \\
\hline $\mathbf{F}$ & 52 & Second & 2 & 2 & + & + & - & - & - & + & - & - \\
\hline $\mathbf{M}$ & 41 & Second 2 & 24 & 2 & + & + & - & - & - & & - & + \\
\hline
\end{tabular}

Table III Clinical features of cases of postacute and relapsing acute pancreatitis

\begin{tabular}{|c|c|c|c|c|c|c|c|c|c|c|}
\hline Sex & Age & $\begin{array}{l}\text { Length of } \\
\text { History } \\
\text { (years) }\end{array}$ & Pain & $\begin{array}{l}\text { Serum } \\
\text { Amylase }\end{array}$ & Alcoholism & Gallstones & $\begin{array}{l}\text { Pancreatic } \\
\text { Calcification }\end{array}$ & $\begin{array}{l}\text { Clinical } \\
\text { Pancreatic } \\
\text { Insufficiency }\end{array}$ & Obesity & Surgery \\
\hline
\end{tabular}

\begin{tabular}{lcr}
\hline \multicolumn{3}{c}{ Chronic pancreatitis } \\
F & 69 & 7 \\
M & 80 & 12 \\
M & 44 & $<1$ \\
M & 38 & $<1$ \\
M & 16 & $<1$ \\
M & 62 & 17 \\
F & 55 & 1 \\
F & 65 & 16 \\
M & 46 & 5 \\
F & 45 & 2
\end{tabular}

Chronic relapsing pancreatitis

$\begin{array}{lll}\text { M } & 55 & \\ \text { M } & 62 & \\ \text { M } & 46 & < \\ \text { M } & 47 & \\ \text { M } & 64 & \\ \text { M } & 67 & < \\ \text { M } & 40\end{array}$

6
2
$<1$
1
2
$<1$
8

$\begin{array}{ll}- & - \\ + & \\ - & - \\ - & - \\ + & \\ + & - \\ + & \\ + & -\end{array}$

$\begin{array}{ll}+ & \\ + & \\ - & \\ - & - \\ - & - \\ - & -\end{array}$

$\begin{array}{ll}- & + \\ - & + \\ - & + \\ - & + \\ - & + \\ - & +\end{array}$

+
-
-
-
+
+
-

$\begin{array}{lll}+ & - & - \\ + & - & - \\ + & - & - \\ - & - & + \\ + & - & + \\ + & + & + \\ + & - & + \\ + & - & + \\ + & - & +\end{array}$

Table IV Clinical features of cases of chronic relapsing and chronic pancreatitis

three with relapsing acute pancreatitis were operated on subsequently for gallstones. Some of the clinical features in these cases are shown in Table III.

The distinction between relapsing acute and chronic relapsing pancreatitis depended first on

\begin{tabular}{|c|c|c|c|c|c|}
\hline & \multicolumn{2}{|c|}{ Controls (32) } & \multicolumn{2}{|c|}{ Chronic Pancreatitis (17) } & \multirow{2}{*}{$\begin{array}{l}\text { Significance } \\
\text { of Difference }\end{array}$} \\
\hline & Mean & $S E$ & Mean & $S E$ & \\
\hline $\begin{array}{l}\text { Volume }(\mathrm{ml}) \\
\text { Resting } \\
\text { After secretin } \\
\text { After pancreozymin }\end{array}$ & $\begin{array}{l}28 \\
73 \\
83\end{array}$ & $\begin{array}{l}4 \\
7 \\
9\end{array}$ & $\begin{array}{l}37 \\
89 \\
82\end{array}$ & $\begin{array}{r}8 \\
20 \\
14\end{array}$ & $\begin{array}{l}\text { None } \\
\text { None } \\
\text { None }\end{array}$ \\
\hline $\begin{array}{l}\text { Bicarbonate }(\mathrm{mm} / \mathrm{l}) \\
\text { Resting } \\
\text { After secretin } \\
\text { After pancreozymin }\end{array}$ & $\begin{array}{l}16 \\
98 \\
92\end{array}$ & $\begin{array}{l}3 \\
5 \\
5\end{array}$ & $\begin{array}{l}10 \\
47 \\
40\end{array}$ & $\begin{array}{l}2 \\
7 \\
6\end{array}$ & $\begin{array}{l}\text { None } \\
\mathrm{P}<0.001 \\
\mathrm{P}<0.001\end{array}$ \\
\hline $\begin{array}{l}\text { Amylase (units/ml) } \\
\text { Resting } \\
\text { After secretin } \\
\text { After pancreozymin }\end{array}$ & $\begin{array}{l}361 \\
254 \\
2 \cdot 27\end{array}$ & $\begin{array}{l}069 \\
0.26 \\
0.20\end{array}$ & $\begin{array}{l}060 \\
0 \cdot 58 \\
0 \cdot 70\end{array}$ & $\begin{array}{l}012 \\
0.09 \\
0.14\end{array}$ & $\begin{array}{l}P<0.001 \\
P<0.001 \\
P<0.001\end{array}$ \\
\hline
\end{tabular}

Table V Results of exocrine pancreatic function tests 


\section{Results}

\section{CHRONIC AND CHRONIC RELAPSING PANCREATITIS}

The cases of chronic relapsing and chronic pancreatitis are considered first, as being of most interest, and the results compared with those of the control cases.

The results of the exocrine pancreatic function tests are shown as means (Table V). In the case of volume of juice, the sums of the 10-minute collections for the resting, postsecretin, and postpancreozymin periods have been taken separately and the means calculated. For bicarbonate and amylase secretion, the highest concentration occurring during each period has been used.

Table VI and Fig. 1 give the results of exocrine pancreatic function tests in the 32 control patients and in the 17 patients with chronic and chronic relapsing pancreatitis.

There was no significant difference in the volume of juice in any period of the tests between the control and the pancreatitic patients. No difference was found in the concentration of bicarbonate during the resting period, but the concentration of bicarbonate after both secretin

\begin{tabular}{|c|c|c|c|c|}
\hline \multirow[t]{2}{*}{$\operatorname{Sex}$} & \multirow{2}{*}{$\begin{array}{l}\text { Age } \\
(y r)\end{array}$} & \multirow{2}{*}{$\begin{array}{l}\text { Exocrine } \\
\text { Function }\end{array}$} & \multicolumn{2}{|c|}{ Endocrine Function } \\
\hline & & & Insulin Curve & $\begin{array}{l}\text { Glucose } \\
\text { Tolerance } \\
\text { Test }\end{array}$ \\
\hline \multicolumn{5}{|c|}{ Chronic pancreatitis } \\
\hline $\begin{array}{l}\mathbf{F} \\
\mathbf{M} \\
\mathbf{M} \\
\mathbf{M} \\
\mathbf{M} \\
\mathbf{M} \\
\mathbf{F} \\
\mathbf{F} \\
\mathbf{M} \\
\mathbf{F}\end{array}$ & $\begin{array}{l}69 \\
80 \\
44 \\
38 \\
16 \\
62 \\
55 \\
65 \\
46 \\
45\end{array}$ & $\begin{array}{l}\text { Abnormal } \\
\text { Abnormal } \\
\text { Abnormal } \\
\text { Abnormal } \\
\text { Abnormal } \\
\text { Abnormal } \\
\text { Abnormal } \\
\text { Abnormal } \\
\text { Abnormal } \\
\text { Abnormal }\end{array}$ & $\begin{array}{l}\text { Flat } \\
\text { Flat } \\
\text { Flat } \\
\text { Flat } \\
\text { Flat } \\
\text { Flat } \\
\text { Delayed rise } \\
\text { Normal } \\
\text { Normal } \\
\text { Normal }\end{array}$ & $\begin{array}{l}\text { Diabetic } \\
\text { Diabetic } \\
\text { Diabetic } \\
\text { Diabetic } \\
\text { Diabetic } \\
\text { Diabetic } \\
\text { Diabetic } \\
\text { Normal } \\
\text { Normal } \\
\text { Normal }\end{array}$ \\
\hline \multicolumn{5}{|c|}{ Chronic relapsing pancreatitis } \\
\hline $\begin{array}{l}\mathbf{M} \\
\mathbf{M} \\
\mathbf{M} \\
\mathbf{M} \\
\mathbf{M} \\
\mathbf{M} \\
\mathbf{M}\end{array}$ & $\begin{array}{l}55 \\
62 \\
46 \\
47 \\
64 \\
67 \\
40\end{array}$ & $\begin{array}{l}\text { Abnormal } \\
\text { Abnormal } \\
\text { Abnormal } \\
\text { Abnormal } \\
\text { Abnormal } \\
\text { Abnormal } \\
\text { Abnormal }\end{array}$ & $\begin{array}{l}\text { Flat } \\
\text { Normal } \\
\text { Normal } \\
\text { Normal } \\
\text { Normal } \\
\text { Normal } \\
\text { Normal }\end{array}$ & $\begin{array}{l}\text { Normal } \\
\text { Diabetic } \\
\text { Normal } \\
\text { Normal } \\
\text { Normal } \\
\text { Normal } \\
\text { Diabetic }\end{array}$ \\
\hline
\end{tabular}

Table VI Exocrine and endocrine pancreatic function

and pancreozymin was significantly lower in the group of patients with chronic pancreatic disease. The mean amylase concentrations were always lower in the patients with chronic pancreatitis
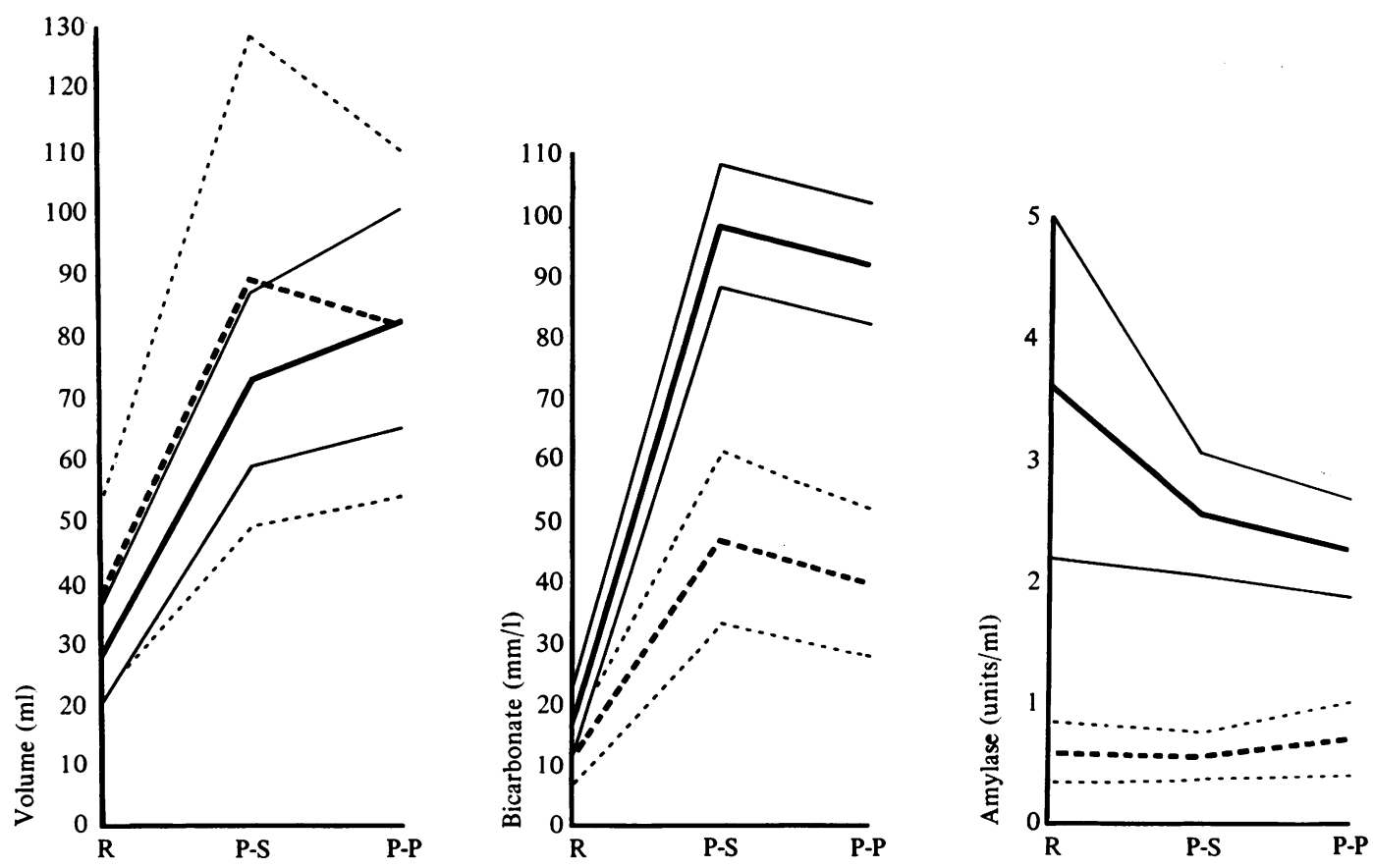

Fig. 1 Mean and two standard errors of results of exocrine pancreatic function tests in 32 control patients and in 17 patients with chronic and chronic relapsing pancreatitis. (a) Volume, (b) bicarbonate concentration, (c) amylase concentration of pancreatic juice. (Control C. Chronic pancreatitis and chronic relapsing pancreatitis $---. R=$ resting, $P-S=$ post-secretion, and $P-P=$ post-pancreozymin.) 
than in the controls. The only patient in the control group who had impaired exocrine pancreatic function was suffering from a glutensensitive enteropathy, with a completely flat jejunal mucosa. He was not severely wasted and the reason for the poor pancreatic function is not apparent. He responded well to a gluten-free diet.

All the patients in the control group had by definition a normal glucose tolerance test. The results of the plasma insulin curves in the control patients and in those with chronic pancreatitis are shown for each individual case in the scattergrams (Figs. 2 and 3) and the means and two standard errors in Figure 4.

Two of the control patients had a flat insulin response curve, but in neither was there any confirmatory evidence of chronic pancreatitis. One patient had a delayed-rise insulin response. The remaining 29 had normal insulin response curves and included the patient mentioned above with impaired exocrine function.

In the chronic relapsing pancreatitis group, the tests of pancreatic function were all carried out more than three months after an acute exacerbation. Of the 17 patients in this and the chronic pancreatitis group, all had abnormal exocrine function. Eight had impaired endocrine function, and of these, seven had a flat insulin response and one a delayed rise curve. With one exception, all these eight patients had a diabetic glucose tolerance curve, and in the exception the result was borderline. Thus all the patients with an abnormal insulin production had abnormal, often markedly so, exocrine function, but the reverse did not apply. The remaining nine patients with chronic pancreatic disease had normal insulin production, but in one of these the glucose tolerance test gave a diabetic curve in spite of the normal insulin response. Thus, of the 10 patients with chronic pancreatitis who were not subject to exacerbations, seven had an abnormal insulin response, whereas of the seven with chronic relapsing pancreatitis only one had an abnormal insulin curve. This difference is striking.

Only one of the 10 patients with chronic pancreatitis gave a past history of an attack of acute pancreatitis. This was a male, now aged 62 , who 17 years previously had been admitted to this hospital with an undoubted attack of acute pancreatitis, a high serum amylase level being found. He had remained well in the interval until six months before he presented, when he developed $\stackrel{?}{?}$ pancreatic steatorrhoea. He had grossly impaired $\vec{F}$ exocrine function, a very flat insulin curve, $\mathscr{\mathfrak { g }}$ and the pancreas was calcified.

\section{ACUTE AND RELAPSING ACUTE}

\section{PANCREATITIS}

The findings in the few patients in these two $\vec{\circ}$ sections are recorded for interest. The clinical features have been given in Table III. Of the three cases with postacute pancreatitis, one who was tested three months after the acute attack had normal exocrine function, whereas two who $\exists$ were examined one month after the attack still $\dot{\sigma}$ had abnormal exocrine tests. One of these had a diabetic glucose tolerance test, but all three had normal plasma insulin response curves.

The three patients with relapsing acute pancreatitis were examined one two, and 24 months respectively after their second attack. All had normal exocrine function, normal glucose tolerance tests, and normal plasma insulin response curves. Two of these three patients had gallstones, which were subsequently removed, while the third, a boy aged 15 at the time he was investigated after his second attack, has subsequently had six further attacks and shows severely impaired exocrine function. At the present time he would be classified as having chronic relapsing pancreatitis.

\section{CARCINOMA OF THE PANCREAS}

Five cases proved to have a carcinoma of the pancreas and details are given in Table VII. In three of the five patients, insulin secretion was impaired. In one a flat insulin response curve and in two a delayed-rise type of curve were found. It is of interest that in one of these patients, at the time he was tested, the exocrine pancreatic function was normal. The number of cases is very small but it is thought that a study of insulin production in patients suspected of early pancreatic carcinoma might prove of value.

\begin{tabular}{|c|c|c|c|c|c|c|c|c|c|c|c|}
\hline \multirow[t]{2}{*}{ Sex } & \multirow[t]{2}{*}{ Age } & \multirow{2}{*}{$\begin{array}{l}\text { Jaundice } \\
\text { at Time } \\
\text { of Test }\end{array}$} & \multirow{2}{*}{$\begin{array}{l}\text { Length of } \\
\text { History } \\
\text { (years) }\end{array}$} & \multirow[t]{2}{*}{ Pain } & \multirow[t]{2}{*}{ Alcoholism } & \multirow{2}{*}{$\begin{array}{l}\text { Clinical } \\
\text { Pancreatic } \\
\text { Insufficiency }\end{array}$} & \multirow{2}{*}{$\begin{array}{l}\text { Pancreatic } \\
\text { Calcification }\end{array}$} & \multirow[t]{2}{*}{ Obesity } & \multirow{2}{*}{$\begin{array}{l}\text { Exocrine } \\
\text { Function }\end{array}$} & \multicolumn{2}{|c|}{ Endocrine Function } \\
\hline & & & & & & & & & & $\begin{array}{l}\text { Insulin } \\
\text { Curve }\end{array}$ & $\begin{array}{l}\text { Glucose } \\
\text { Toler- } \\
\text { ance } \\
\text { Test }\end{array}$ \\
\hline $\begin{array}{l}\mathbf{M} \\
\mathbf{M} \\
\mathbf{M} \\
\mathbf{M} \\
\mathbf{M}\end{array}$ & $\begin{array}{l}74 \\
67 \\
58 \\
66 \\
56\end{array}$ & $\begin{array}{l}\overline{+} \\
\bar{z} \\
\overline{-}\end{array}$ & $\begin{array}{r}5 \\
<1 \\
2 \\
<1 \\
<1\end{array}$ & $\begin{array}{l}\frac{+}{+} \\
\frac{t}{+}\end{array}$ & $\begin{array}{l}\bar{z} \\
\bar{z} \\
\bar{z}\end{array}$ & $\begin{array}{l}\overline{+} \\
\dot{+} \\
-\end{array}$ & $\begin{array}{l}\bar{z} \\
\bar{z} \\
\bar{z}\end{array}$ & $\begin{array}{l}\bar{t} \\
\bar{z} \\
-\end{array}$ & $\begin{array}{l}\text { Abnormal } \\
\text { Abnormal } \\
\text { Abnormal } \\
\text { Normal } \\
\text { Abnormal }\end{array}$ & $\begin{array}{l}\text { Delayed rise } \\
\text { Normal } \\
\text { Delayed rise } \\
\text { Flat } \\
\text { Normal }\end{array}$ & $\begin{array}{l}\text { Normal } \\
\text { Normal } \\
\text { Normal } \\
\text { Normal } \\
\text { Normal }\end{array}$ \\
\hline
\end{tabular}

Table VII Clinical features, exocrine, and endocrine pancreatic function in patients with carcinoma of the pancreas 


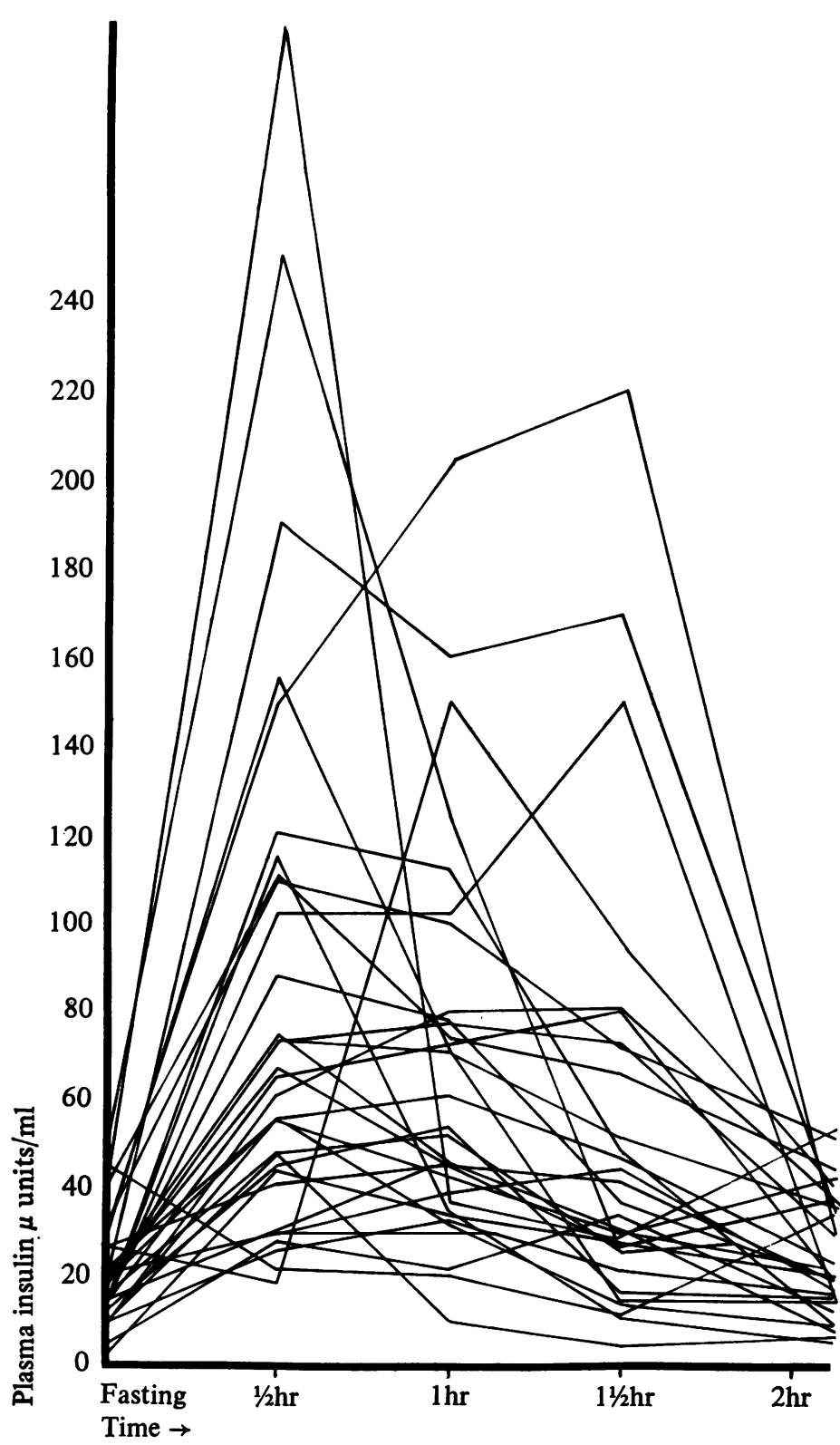

Fig. 2 Plasma insulin response curves in control patients.

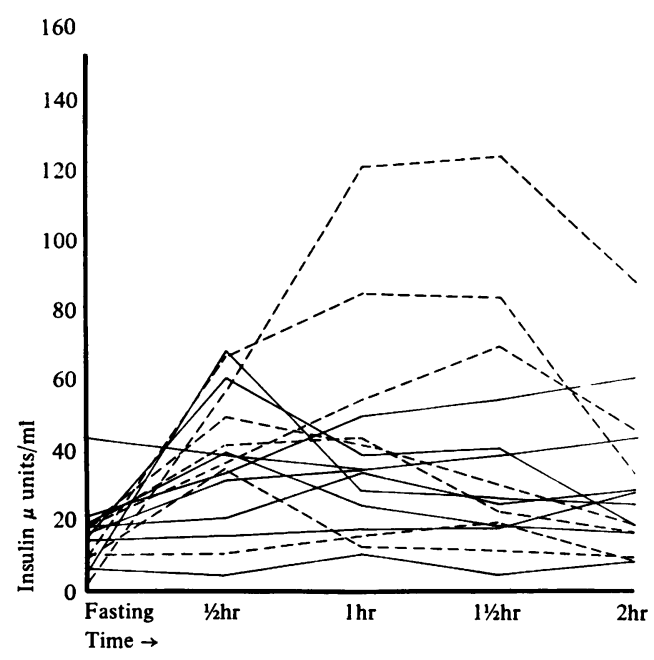

Fig. 3 Plasma insulin response curves in patients with chronic and chronic relapsing pancreatitis. (- chronic pancreatitis, - - - - chronic relapsing pancreatitis.)

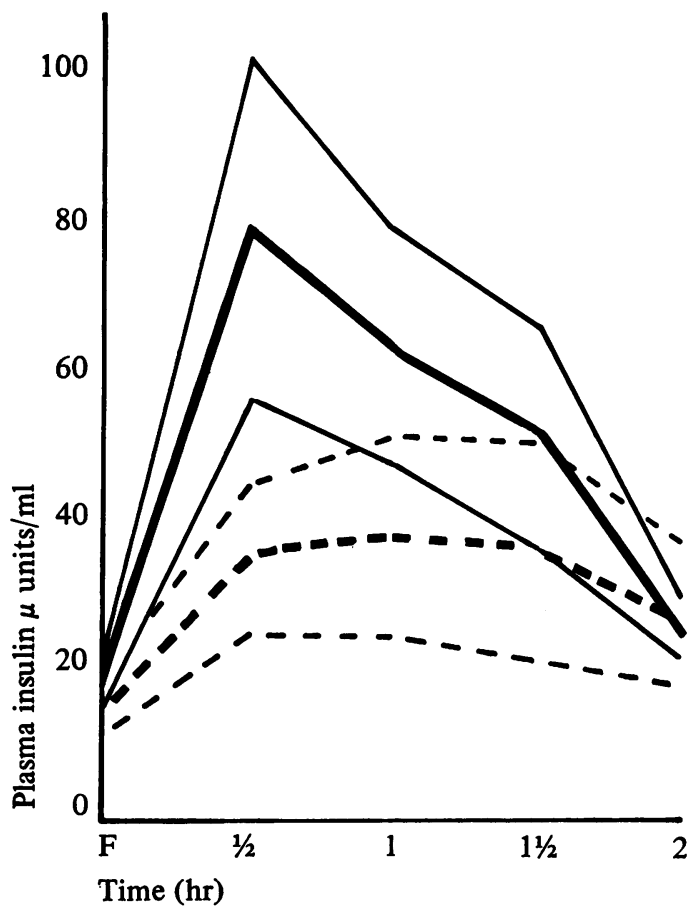

Fig. 4 Means, and two standard errors, of plasma insulin curves in 32 control patients and in 17 patients with chronic and chronic relapsing pancreatitis. (Control $\longrightarrow$, chronic and chronic relapsing pancreatitis - - .) 
HAEMOCHROMATOSIS

Only two patients with haemochromatosis were studied. In both there was definite histological evidence of the diagnosis on liver biopsy, and both had an abnormally high serum iron-binding capacity. The exocrine pancreatic function test in one of these was abnormal, showing an increased postsecretin volume of juice and a reduced concentration of bicarbonate and amylase throughout. In this patient the plasma insulin curve was normal. The other patient had normal exocrine pancreatic function, but his insulin response curve was flat. This patient had a diabetic glucose tolerance test and was currently being treated with chlorpropamide.

FIBROCYSTIC DISEASE

Only one patient with fibrocystic disease was examined. He was a boy of 16 who had abnormal exocrine function, a delayed rise in the plasma insulin curve, but a normal glucose tolerance test.

\section{DIABETES MELLITUS}

The findings in the 11 patients finally placed in the diabetes mellitus group are shown in Table VIII. In fact, of the 11 patients originally presenting with diabetes, four had a flat insulin curve. One of these subsequently developed frank steatorrhoea, and another was found to have a raised fat content in the stools, both showing impaired exocrine function on testing. As mentioned above, these two cases were regarded as having chronic pancreatitis. The other two patients in this group with a flat insulin response have shown no evidence of diffuse pancreatic disease to the present time. The individual insulin curves of the patients with diabetes mellitus are shown in a scattergram (Fig. 5).

\begin{tabular}{|c|c|c|c|c|c|c|c|}
\hline & \multicolumn{2}{|c|}{ Exocrine Function } & \multicolumn{5}{|c|}{ Endocrine Function } \\
\hline & \multirow[b]{2}{*}{ Normal } & \multirow[b]{2}{*}{ Abnormal } & \multicolumn{3}{|c|}{ Insulin Curve } & \multicolumn{2}{|c|}{$\begin{array}{l}\text { Glucose } \\
\text { Tolerance Test }\end{array}$} \\
\hline & & & Normal & Flat & $\begin{array}{l}\text { Delayed } \\
\text { Rise }\end{array}$ & Diabetic & Normal \\
\hline $\begin{array}{l}\text { Obese } \\
\text { Not obese }\end{array}$ & $\begin{array}{l}3 \\
8\end{array}$ & - & $\begin{array}{l}1 \\
1\end{array}$ & $\overline{2}$ & $\begin{array}{l}2 \\
5\end{array}$ & $\begin{array}{l}3 \\
8\end{array}$ & - \\
\hline
\end{tabular}

Table VIII Exocrine and endocrine pancreatic function in patients with diabetes mellitus

\section{Discussion}

It would appear that, in chronic pancreatitis, exocrine function is impaired before endocrine function when the latter is measured by insulin production in response to a glucose load. In approximately half of our patients with known pancreatic damage and impaired exocrine func-

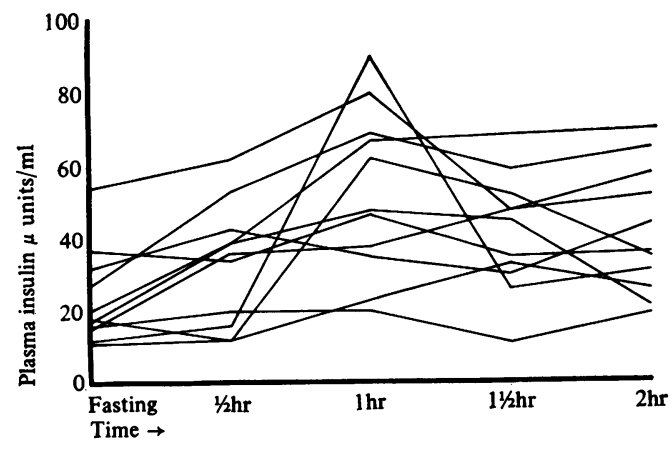

Fig. 5 Plasma insulin response curves in diabetic patients.

tion, the insulin response was normal. It may be that if the islet cells are subjected to intensive stimulation, as in the method employed by Joffe et al (1968), an abnormality can more often be demonstrated, as they found in all their 16 patients. Linquette et al (1968) report abnormal insulin production in all but four of 28 cases of chronic pancreatitis. Their criteria of abnormality are, however, different from those used in this study, in that they regard as abnormal curves which have a normal rise but remain high, socalled 'plateau' curves. In the present context we have only considered a delayed rise or a failure to rise to more than twice the fasting figure as indicating impaired insulin production. According to the criteria used by us, nine out of 28 of their curves would have been regarded as flat, four as showing a delayed rise, while the remainder would have been classed as normal.

Ohlsen (1968) produced various indices of insulin response to glucose using a glucose infusion test with measurement of plasma insulin. He found that most of the 20 patients with chronic pancreatitis tested had a low initial o insulin response. There was, however, a con- N siderable overlap between patients and control cases. The fasting plasma insulin levels in both his control cases and patients were much higher than the levels normally reported by other workers and this may have affected the assess- @ ment of the insulin response to glucose.

It is considered that the criterion of the flat insulin response, defined above, enables cases $\mathbb{\mathbb { D }}$ with reduced insulin production to be separated $\frac{}{\mathbb{D}}$ clearly from those with normal insulin output.

Only one out of seven cases of chronic relapsing pancreatitis showed impaired insulin produc- $\delta$ tion, as compared with seven out of 10 patients with chronic pancreatitis without exacerbation. 흑

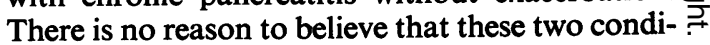
tions are fundamentally different. In our small 
series, both groups contained alcoholic patients and pancreatic calcification occurred in some instances. It may be that in the cases of chronic pancreatitis without exacerbation, half of whom had no pain, the disease process had been present for some years, before presenting, for example, with steatorrhoea. The mode of presentation in chronic relapsing pancreatitis with severe pain leads to earlier diagnosis, and it may be that many of the islet cells at this stage are still undamaged. The only patient with chronic relapsing pancreatitis who had endocrine impairment had a six-year history of attacks, and was indeed the only patient with chronic relapsing pancreatitis to have frank steatorrhoea, although all the cases had abnormal exocrine function.

How often a flat insulin response curve may be the first indication of diffuse pancreatic disease is not known, but it seems likely that this may occur on occasion. Of four patients presenting with diabetes mellitus and found to have flat insulin curves, two showed evidence of pancreatic insufficiency on further investigation. One of the patients with a carcinoma of the pancreas had a flat insulin curve at a time when his faecal fat and exocrine function were normal.

The postmature diabetic patient, as a general rule, has a normal or raised fasting plasma insulin but often shows a delayed rise after glucose, the curve then remaining high and not returning to the fasting level within two hours. When a flat insulin response is found in an apparently straightforward case of postmature diabetes, what is the explanation? It would at any rate appear that it is worth investigating such cases for evidence of chronic pancreatitis or possibly a neoplasm. Whether there is a group of ordinary postmature diabetics in whom the insulin curve is flat remains to be elucidated.
Patients with chronic pancreatitis and relatively severe insulin deficiency often show less loss of glucose tolerance than patients with postmature diabetes mellitus. In chronic pancreatitis, a loss of pancreatic islet alpha cell function and glucagon production may partially compensate for insulin deficiency.

Plasma insulin curves may contribute substantially to the investigation of individual cases of pancreatic disease. A low insulin output supports the diagnosis of diffuse pancreatic disease and its finding may indicate damage of some severity. It may prove to be of value in the early diagnosis of carcinoma of the pancreas. Conversely, in a patient presenting with diabetes mellitus, in whom any suspicion of chronic pancreatitis or a neoplasm arises, a low insulin response curve is an indication for further investigation.

\section{References}

Burton, P., Evans, D. G., Harper, A. A., Howat, H. T., Oleesky, S., Scott, J. E., and Varley, H. (1960). A test of pancreatic function in man, based on the analysis of duodenal contents after the administration of secretin and pancreozymin. Gut, 1, 111-124.

Conn, J. W. (1958). The prediabetic state in man. Diabetes, 7 , 347-357.

Hales, C. N., and Randle, P. J. (1963). Immunoassay of insulin with insulin-antibody precipitate. Biochem. J., 88, 137-146.

Joffe, B. I., Bank, S., Jackson, W. P. U., Keller, P., O'Reilly, I. G., and Vinik, A. I. (1968). Insulin reserve in patients with chronic pancreatitis. Lancet, 2, 890-892.

Linquette, M., Fossati, P., Fourlinnie, J. C., and Paris, J. (1968). Les variations de la radio-insulinémie dans les pancréatites chroniques. Ann. Endocr. (Paris), 29, 253-261.

Ohlsen, P. (1968). Endocrine and exocrine pancreatic function in pancreatitis. Acta med. scand., suppl. 484.

Peters, N., Dick, A. P., Hales, C. N., Orrell, D. H., and Sarner, M. (1966). Exocrine and endocrine pancreatic function in diabetes mellitus and chronic pancreatitis. Gut, 7, 277-281.

Wincey, C., and Marks, V. (1961). A micro method for measuring glucose using the AutoAnalyzer and glucose oxidase J. clin. Path., 14, 558-559. 